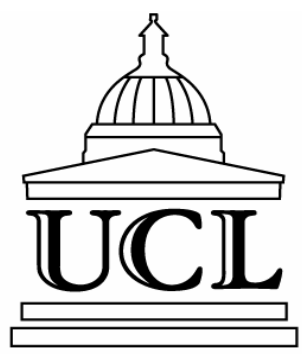

CENTRE FOR THE STUDY

OF ECONOMIC \& SOCIAL

CHANGE IN EUROPE

SCHOOL OF SLAVONIC \& EAST

EUROPEAN STUDIES

\title{
Post-Communist Recessions Re-examined
}

Tomasz M. Mickiewicz

Department of Social Sciences

SSEES, University College London,

E-mail: t.mickiewicz@ssees.ucl.ac.uk

Working Paper No. 55

University College London

Centre for the Study of Economic and Social Change in Europe

Senate House, Malet Street, London, WC1E $7 \mathrm{HU}$

Tel: 44(020) 78638517

Fax :44(020) 78628641

Email: csesce@ssees.ac.uk 
Working Paper No. 55

June 2005

\begin{abstract}
:
We apply simple econometric methods to evaluate the factors that determined the length and depth of the post-Communist recessions. Early implementation of the stabilisation and liberalisation programmes made the recessions weaker. Wars had strong negative impact. Initial trade dependence made recessions more serious. The results are discussed with reference to the existing explanations of the 'transitional recessions', in particular Calvo and Coricelli (1992, 1993), Blanchard and Kremer (1997) and Blanchard (1997).
\end{abstract}

JEL Classification: P24, P30

Key Words: Transition, Recession

\title{
Acknowledgements:
}

I am grateful to Chris Gerry, Mariusz Jarmużek and the participants of the MET Workshop at Brighton for critical comments 


\section{Recessions}

In this paper we wish to explore the determinants of the Post-Communist recessions, i.e. recessions experienced during the 1990s by the 27 countries that emerged from the Soviet block. As will be discussed in detail, most of the transition theory focused on the related but different concept of 'transitional recession', , i.e. the recession following the implementation of liberalisation programme.

Empirically, this 'transitional recession' is a part, but only a part of the experience of post-Communist economies. From empirical studies on economic growth in the region we know that the 'transitional recession' was a real phenomenon, however it corresponded to the 'J-curve' path of output, i.e. was relatively short and led to subsequent higher growth. In some countries, this short transitional recession was the only recession that was experienced. In Poland the recession was two years long. In the neighbouring Ukraine (and in Moldova) it took ten years for the economic growth to recover.

Moreover, the timing of recessions did not always coincide with the introduction of the core liberalisation programme. Out of twenty seven former command economies in Europe and the former Soviet Union, twelve went into recession already in 1989, twelve more joined in 1990 and virtually all post-Communist economies were in recession in 1991 (see Table A.1 at the end of this paper). More importantly, those were not 'transitional' recessions: twenty five economies went into recession before the stabilisation or liberalisation programmes were implemented. The only two exceptions are Hungary and Poland. In Hungary, GDP growth reported for 1989 was close to zero, i.e. 0.4\%. Stabilisation programme was introduced in March 1990 and the economy went into recession in the same year. However, the level of liberalisation corresponding to Polish reforms of 1990 was reached in Hungary only two years after the recession started, i.e. in $1992 .^{2}$ That leaves us with Poland as the only single example where beginning of recession coincided with introduction of the full liberalisation and stabilisation programmes. Indeed, in 1989, the Polish GDP seemed

\footnotetext{
${ }^{1}$ The term may be attributed to Janos Kornai (1995).

2 This delay led to (now mostly obsolete) discussion of 'gradualism' versus 'big bang', where Hungary was taken as an example of the former, and Poland of the latter. A sampling of that early discussion can be found in Portes (1993).
} 
to be still growing at the rate of $2.8 \%,{ }^{3}$ albeit inflation was soaring and it is disputable how long the growth could last. The stabilisation and liberalisation programmes were introduced in January 1990, and the economy immediately went intro recession, which lasted for just over two years; as it turned out later, the shortest period as compared with any other transition economy.

This short account is intended to reiterate that the command economies were already in crisis in late 1980s. Liberalisation introduced in early 1990s was a response to this crisis. While it made recession worse for a short period of time, it also led to faster recovery.

\section{Empirical literature}

There are two lessons emerging from the empirical literature on economic growth in the region: (i) both transitional reforms and stabilisation was conducive to economic growth in the longer run, however (ii) the reforms resulted in J-curve short term output paths as did some types of stabilisation policies (but not all).

We will discuss those two results in turn.

Econometric evidence on output response to reforms can be found in seven published studies on economic growth in the region based on panel data: Loungani and Sheets (1997), Selowsky and Martin (1997), Christoffersen and Doyle (2000), De Melo et al. (2001), Falcetti et al (2002), Havrylyshyn and van Rooden (2003) and Merlevede (2003). All the studies are consistent in finding that overall impact of reforms (as measured by EBRD indicators) on economic growth is positive. At the same time, the reforms result in temporary output slump in the year of implementation, which is counterbalanced by lagged effects. Thus, in the six studies which allow for lagged effects (i.e. except for Loungani and Sheets 1997), we have the same consistent pattern of J-curve type response of output to reforms.

\footnotetext{
${ }^{3}$ For both Hungary and Poland, the output statistics are as reported by the corresponding Central Statistical Offices for GDP, not for the Net Material Product. The latter measure, standard under the old regime, excludes a major part of the service sector. The difference is not trivial. For both countries use of NMP would show recession in 1989 (the latter statistics is sometimes being confused with GDP and made its way into some Western reports, in disguise).
} 
The second set of results relates to the link between macroeconomic stabilisation and output. In the studies quoted above, empirical results show that macroeconomic instability (measured either as high inflation or low (negative) government budget balance) affects growth negatively. There is no indication of the short term positive correlation between inflation and growth (and of negative impact of disinflation on growth). Campos and Corricelli (2002) summarise the existing evidence in light of theoretical insights, noting:

... based on the experience of programmes implemented in developing market economies, stabilisation per se should not have caused a sharp fall in output (Ibid., p.819)

All this evidence, still does not exclude the possibility that some types of stabilisation programmes could have negative impact on growth. As far as we know, the only published econometric evidence on impact of stabilisation programmes, which distinguish between different types and based on cross-country panel of transition economies, comes from Christoffersen and Doyle (2000). They did not find any systematic, general impact of stabilisation on output (other than positive via disinflation), This can be easily corroborated by evidence provided in Table A.1 below. The only two countries, where the beginning of recession coincided with stabilisation, were again Hungary and Poland. However, Christoffersen and Doyle (2000) found one significant effect: where sharp disinflation (inflation more than halved in one year) was implemented under the presence of pegged exchange rate regime, the policy had a negative effect on growth. Even in this case however, the longer run impact of these programmes should be positive, as short term negative effects may be counterbalanced by subsequent positive impulse of macroeconomic stabilisation on growth.

In the next section (3) we will consider theoretical explanations of the link between the systemic reforms and output path. In subsequent Section 4, we wish to focus on the empirical analysis: which set of factors explains the length and depth of recessions experienced by the group of post-Command economy countries. Because those recessions did not necessary coincide with 'transitional' recessions proper (i.e. those resulting from the systemic reforms, which have short-lived negative impacts on 
growth), a better name to use would be 'post-Communist' recessions. As will be argued, it is not transition and stabilisation, but absence of those which imposed the most serious economic cost on the group of countries we consider.

\section{Theoretical literature on 'transitional recession'}

As already discussed, the 'transitional recession', triggered by liberalisation, even if short lived was a real phenomenon and of considerable interest from the economic theory point of view. It is not frequent that a large group of countries decide to dismantle the command economy. And again, the timing of this systemic transition is best represented by liberalisation. Institutional reforms took longer to implement, and empirically, it was typically liberalisation, which coincided with a large one-off decrease in output (even if the recession started earlier, as already discussed). Before discussing the explanations of the 'transitional recessions', it is worth to notice two themes featuring frequently in the literature, where the term 'transition' not necessary applies:

Firstly, the evidence discussed already shows that some types of stabilisation programmes had temporary negative impact on GDP growth. However, the experience of the transition economies does not differ here from other middle income market economies, Latin America in particular. The transition countries inherited monetary overhangs resulting from initial price controls, which imply that liberalisation could result in one-off price jump, which could trigger a policy response in the form of stabilisation programmes. However, the macro disequilibria to be addressed were more deeply rooted than just the effects of price liberalisation. And whatever the initial reason, the stabilisation programmes were addressing the macro disequilibria which were qualitatively not very different from any other market type economies. Generally, it is not the macro policy, where the transition experience has some unique features.

Secondly, foreign trade shock were real, but should not be related to individual liberalisation programmes. Disappearance of trade structures co-ordinated by CMEA (Council of Mutual Assistance) and disruption of the intra-Soviet trade within the former Soviet Union (fifteen out of twenty seven transition countries were Soviet republics in 1989) led to trade shocks. Thus, more trade dependent countries were 
more affected by recessions. A possible link to liberalisation is that the old administrative foreign trade links were disrupted, before they could be substituted by new ones based on international market mechanisms. However, there are two problems with this line of argument. Firstly, the effects would appear regardless of liberalisation in a given country - it is sufficient than the neighbouring countries liberalise. And secondly, a more important effect there is not that the old coordinating mechanism was replaced by market structures. In fact, trade openness was associated with better trade and output performance, as exemplified by Estonia, and several other Central European countries. The problem was rather that the old coordinating mechanism was not replaced by international market arrangement but by new set of barriers and inefficient exchange rate mechanisms, in particular in the CIS countries (see Gros and Steinherr 2004).

This leaves us with explanations of 'transitional' recessions that may be grouped under two main headings; those may be seen more as complementary then alternatives:

1. Shocks in relative prices resulting from price liberalisation. That is typically exemplified by the two following channels. The first one relates to the elimination of soft-budget constraint (i.e. introducing 'hard' credit and reduction/elimination of budgetary subsidies to enterprises), which results in a different set of producer prices (Blanchard 1997). The second channel relates to the direct shift of prices of energy (and energy-intensive products) towards world prices (even if energy prices were not liberalised fully, the prices were at least partially adjusted upwards) (McKinnon 1993). There are two possible mechanisms linking change in producer prices with recession. Firstly, financial market imperfections may imply that firms with good projects have no resources to expand quickly, while firms with bad projects are immediately hit and reduce output. Recession follows (Calvo and Coricelli 1992). Secondly, firms hit by price shocks are unable to adjust their labour costs downwards. Reduction in both employment and production follows (Blanchard 1997). 
2. Disorganisation. Dismantling of the command economy mechanism leaves individual firms with a large set of bargaining problems with their suppliers and customers. In some areas, market equilibrium prices may quickly emerge, but in some other informational barriers may lead to strategic behaviour and inefficient outcomes, where some productive links will be broken down. In short, while new co-ordination mechanism based on prices emerges ultimately, it may take time to establish it, and output fall is more likely in industries with a large number of rigid connections between producers of intermediate goods. This empirical prediction is confirmed by Blanchard and Kremer (1997).

In the Blanchard's (1997) version, the first model (under the name of 'reallocation') relies on the labour market mechanisms not on the financial sector imperfections. It starts with the distinction between those firms, which lost from shift in relative prices, and those which gained. In the first category we find firms that were subsidised under the old system, in the second those which had to pay the cost of it in terms of higher taxes. The losers (the 'old' sector) may be identified with the state sector, and the gainers with the new private sector or with firms restructured after privatisation ('new' sector). Alternative categorisations are possible: 'old sector' label may be attributed to firms controlled by insiders (both 'old' state and privatised to insiders) and 'new sector' to firms, where either outsiders or owners-managers (entrepreneurs in case of small firms) are in control. The key economic distinction relates to the fact that the 'new' sector is more productive - in the Blanchard's model, the quality of a representative consumer good produced is higher, and old equilibrium was supported by the fiscal distortions (subsidies and taxes) and resulting price distortions.

Elimination of the fiscal intervention makes the prices of the goods produced by both sectors equal, and the consumer demand shifts towards the 'new' sector due to the positive quality differential. If wages in the 'old' sector adjust downwards, there are no negative effects on employment and production, otherwise transition leads to an initial increase in unemployment and a slump in production. 
In Calvo and Coricelli version $(1992,1993)$ companies face shift in costs resulting either from removal of subsidies or higher prices of energy-related products. 'Bad' firms (those for which command economy distortions were favourable) are hit immediately and reduce production while good firms cannot adjust fast, as they face credit constraints (and investment processes take time). Recession follows:

Over time, firms can accumulate monetary balances and converge to the optimal level of output that would have been reached in the presence of perfect credit markets. Accordingly, the implied behaviour of output would follow a U-shaped pattern. An implication of this view is that output decline should be accompanied by a decline in productivity. Moreover, real wages would drop as well, as enterprises attempt to generate liquidity to purchase inputs (Campos and Coricelli 2002, p. 820).

That is, there is a direct link between the credit market and labour market explanations. However, the Blanchard's model imposes stronger labour market rigidity assumptions that the Calvo and Coricelli's model. In the latter, wages can adjust downwards, and in fact this is to be expected, along the lines quoted above: credit constraint implies that it is not only in the interest of producers of 'bad' products, but also of 'good' producers to cut wages, temporarily. However, wages can neither go down to zero, nor become negative (so that firms could borrow from the employees). Workers are restricted by their access to credit and by their risk preference, and have some non-negative reservation wage. Thus, there are limits to which the internal finance can be generated by drop in real wages (wages cannot become negative, for instance). ${ }^{4}$ That explains why firms producing 'good' products cannot accumulate financial resources quickly enough to expand production. However, recession results also from the fact that wages in firms producing 'bad' products cannot cut wages deep enough to match the impact of slump in product prices, and the latter effect is parallel to the Blanchard's model.

\footnotetext{
${ }^{4}$ Here, wage cuts is one mechanism and wage arrears is another. Wage arrears can be seen as equivalent to borrowing from workers. Modelling of this issue is provided by Earle and Sabirianova (2000). Se also, Desai and Idson (2000, Chapter 8).
} 
The second model (disorganisation) has been presented by Blanchard and Kremer (1997) and Blanchard (1997) in two related versions, either describing a representative production chain or a representative firm facing a number of suppliers. In both cases, previous to liberalisation, the co-ordination was imposed by the economic administration of the command economy system. Liberalisation leads to outside opportunities being open to all parties involved. The possible inefficiency results from the fact that the suppliers and purchasers of intermediate products have to negotiate prices. Bargaining under informational asymmetries may lead to inefficient outcomes, where efficient links are broken, as the suppliers may chose alternative trade partners, even if the real opportunity cost exceeds the benefit.

With benefit of the hindsight, what can we say about the empirical explanatory power of the alternative 'transitional recession' models? The first issue to consider is wage flexibility. Contrary to some expectations, wages turned out to be flexible downwards, at least during the 'transitional recessions'. That is consistent with the model stressing financial constraints and inconsistent with the model stressing labour market rigidities. However, additional theoretical insights may be gained from a reference to the labour controlled model of enterprise, of which state firms at the onset of transition could be clear exemplification. An expected result is that while employment is less flexible, wages may in fact be more flexible in the state firms during the recession. Here, first argument hinges on the impossibility of complete inter-temporal contract between owners (or managers) and employees in private firms. In the latter, workers may be unwilling to accept wage cuts, because they cannot be guaranteed to participate in future rents resulting from successful restructuring. The problem may be easier to overcome in workers owned companies. Secondly, insider ownership may be seen as equivalent to the 'efficient contract' solution, where not only wages but also employment is taken into account in firms' optimisation decisions and the employment effects of higher wages are taken into account, in contrast to no-coordination, 'right to manage' models. The argument, which highlights a counter balancing negative effect however is that the worker may discount the future gains more than the private investor, and therefore may opt for higher wages now at cost of future gains. This again, assumes imperfect financial markets, demonstrating how strong the link between the finance and labour 
perspectives is. In general, however, wage flexibility turned out to be high, either due to the financial reasons, as presented by Campos and Coricelli (2002) cited above, or due to the implications of the effective employee control in the state sector (with the first two effects out weighting the third one). ${ }^{5}$

Secondly, the additional empirical support for the financial explanations of the 'transitional recession' comes from the well documented fact that underdeveloped financial intermediation had been one of the few most characteristic features distinguishing the transition economies from other (Gros and Suhrcke 2000; Gros and Steinherr 2004).

We now turn to empirical evidence.

\section{New empirical results: initial conditions, wars, stabilisation, liberalisation and the Post-Communist slump in output}

We intend to look for a possible set of factors that can explain the recessions experienced by the post-Communist economies during the 1990s. There is more than one way of measuring the economic cost of recession. Moreover, presence of serious measurement errors (Aslund 2001) calls for the use of a battery of alternative indicators, to check the robustness of results. We propose to focus on four alternative measures.

The first one is the depth of recession, as measured by the ratio of the lowest value of output to its 1989 value. For most countries, the indicator was provided directly by EBRD (1999, Table 3.1, p. 63), however, here it was verified for the two countries which were still in recession in 1999 (Ukraine and Moldova) and supplemented for the missing countries (Bosnia and Hertzegovina, Serbia and Montenegro) using EBRD and World Bank statistics. The indicator shows that the recession has been most shallow in the Czech Republic and the most dramatic in war-torn Bosnia and Herzegovina.

The second measure relates to the length of recession. Here, the range of outcomes varies between two years for Poland and ten years for the neighbouring Ukraine and also Moldova.

\footnotetext{
${ }^{5}$ For a general discussion of the employee control during the transition, see Earle and Estrin (1996).
} 
The third measure is a close correlate. Instead of the length, it measures the time span between 1989 and the exit from recession. Thus, while the former measure shows lower values for countries that entered recessions later, the latter is defined by the timing of the final entry on the post-Communist positive growth path. The indicator can be easily computed from the fifth column of Table A.1. It has some advantage over the previous one, if we take into account that the early output statistics may be more problematic for some of the transition economies, and in contrast there is little measurement error related to timing of exit from recession.

Finally, the fourth indicator is a crude proxy for the overall cost of the recession, as measured by a combination of both depth and length. It is calculated as a product of the depth of output slump in the lowest point and the length of recession. ${ }^{6}$

The set of explanatory variables used is based on information provided in Tables A.1 and A.2.

We follow the existing research tradition, where the timing of beginning of transition is interpreted as equivalent to the introduction of some basic set of liberalisation measures. This approach is used in more recent of the empirical studies quoted above, in particular in De Melo et al. (2001), Falcetti et al. (2002), Merlevende (2003), where the time dimension is adjusted taking the starting point to be when the basic set of liberalisation measures was implemented. Similar approach is presented by Blanchard (1997). However, the most explicit discussion of measurement and empirical application of the threshold level of reforms can be found in earlier work by De Melo and Gelb (1997). We follow this tradition, where reforms are split along two dimensions: liberalisation and institutional reforms. For sake of comparability, we opt for a measure used in empirical studies discussed above, and based on the same set of indicators, namely on a simple average of the three EBRD indicators, measuring (i) price liberalisation, (ii) external trade liberalisation, (iii) small privatisation and freedom of entry. Liberalisation threshold is defined as time when this average reaches 3 (which is equivalent to the Polish score in 1990). The data comes from Falcetti et al. (2002) and EBRD (1994-2004) taking into account that the price

\footnotetext{
${ }^{6}$ When divided by two, it gives a rough measure of the area of output loss, but this additional transformation is spurious - it is just a linear transformation, not affecting estimation results in any other way.
} 
liberalisation indicator was re-defined by EBRD from 2003 onwards, with new value of 4 being equivalent to the old value of 3 (we rely on old definifition). One may note, that using this criterion, at time of writing, there was no liberalisation in Belarus, Turkmenistan and Uzbekistan. EBRD indicators cover institutional reforms as well. However, unlike liberalisation, those were spread over a longer period of time. Moreover, the theoretical arguments linking output slumps with reforms relate to liberalisation components.

Stabilisation dates are taken from EBRD (1999). However in few cases, where the repeated attempts at stabilisations were undertaken (i.e. the first programme was unsuccessful), the date of latest programme is used.

Timing of both liberalisation and stabilisation programmes is measured in the following way. In both cases, we divided the observations roughly into two halves, creating dummy variables, which represent 'early' and 'late' implementation of the liberalisations and stabilisations correspondingly. The resulting cut-off point divide stabilisation programmes into those introduced in 1992 or earlier and those implemented after 1992. For liberalisation, the corresponding year is 1994. Our motivation to construct the variables this way, is to minimise the problem of endogeneity of reforms. We intend to explore how early implementation of liberalisation and stabilisation measures affected recessions over the long term. In contrast, any measure based on subsequent paths of reforms may be endogenous, i.e. affected by economic growth.

Next, we have a set of variables corresponding to the initial conditions. ${ }^{7}$ Firstly, we have 'years under communism', an indicator based on the assumption that the longer time span under the old regime, the more distortions were introduced and the more difficult is the return to a market economy. With this measure, some degree of arbitrariness is unavoidable; for consistency, we follow figures by Fisher and Sahay (2000), being fully aware that there may be reasons to modify some of their entries. Next measure - an indicator of the rich natural resource base is also based on the same source, but measurement appears less problematic. The next three indicators of initial conditions are based on De Melo et al. (1997). The first two are measures of repressed inflation and the black market exchange premium at the onset of reforms. Unfortunately, both cannot distinguish between half of the observations in our

\footnotetext{
${ }^{7}$ The list of the indicators is not complete. See Campos and Coricelli (2002) for further discussion.
} 
sample; that is, the reported value is exactly the same for the fifteen countries emerging from the former Soviet Union. For this reason both measures may be strongly correlated with some other omitted variables and therefore remain problematic. The third indicator - a measure of trade dependence on other command economies is better in this respect, as it distinguishes between the former Soviet republics, based on data on intra-Soviet trade.

Finally, we wish to explore if being the former federation counts; the corresponding indicator takes a value of one for countries emerging from Soviet Union, Yugoslavia and Czechoslovakia, and zero otherwise. We also investigated if the narrower dummy, for CIS only, captures some specific influences.

\subsection{Results}

Most of the indicators correlate with recession measures with expected sign. The strongest effect links war with depth of recession (correlation between the war dummy and the lowest/1989 output ratio is $-67 \%){ }^{8}$ Similarly, both time spent under communism, and inherited disequilibrium (repressed inflation, black market exchange rate premium) correlate with recession well. Initial trade dependency made things worse, as more open economies were more exposed to the initial disruptions in trade. Being a federation does not have such a clear impact on recessions, due to the fact that the indicator includes three successful economies: Czech Republic, Slovakia and Slovenia. Being a CIS country on the other hand is significantly linked with recession.

Possibly, the most interesting results relate to timing of liberalisation and stabilisation programmes. First, the time discrepancy between stabilisation and liberalisation correlates with recession indicators. When we take the absolute value of the time difference between the stabilisation and liberalisation programmes, and correlate it with the lowest/1989 ratio of output, the correlation coefficient is $-29 \%$. However, the effect is dominated by simple measures of timing of both programmes. Correlation coefficient between early stabilisation (as defined above) and the lowest/1989 ratio of output is a hefty $54 \%$; for early liberalisation it is almost the same at $53 \%$.

\footnotetext{
${ }^{8}$ However, a word of caution is needed. Aslund (2001) argues that countries experiencing wars were not only affected by the collapse of output, but also by the collapse of output statistics.
} 
Unambiguous result is that early introduction of both liberalisation and stabilisation programmes correlates with less serious recession.

Things become more challenging however, as soon as we move from bivariate correlations to multivariate regression models. The sample is small, and does not allow for models with larger number of variables. Moreover, results are sensitive to specification due to multicollinearity. What emerges from regression analysis is that war remains a single variable with a clear and robust impact on the depth of recession and therefore on the overall cost of recessions, but not on the length of recessions. Next in ranking come three factors: timing of stabilisation, timing of liberalisation and initial trade dependence. However, here multicollinearity between liberalisation and stabilisation measures becomes a problem. While, when measured by simple correlation, the link between timing of liberalisation and recession was almost as strong as the link between timing of stabilisation and recession, as soon as we move to the multivariate regression settings, the effect of early liberalisation becomes dominated by early stabilisation.

Why is the positive impact of early stabilisation so strong? Delay in successful stabilisation programmes was itself an indicator of the more fundamental problems with the fiscal side, i.e. problems with tax collection, tax structure, and control over public expenditures. All these reflect the most important aspects of inadequate institutional reforms. One may also note that those issues are not captured by the EBRD indicators of insititutional reforms, as those do not cover fiscal issues (apart from one important dimension, i.e. 'soft budget' constraints for firms).

Table A.3 presents regression results. The reported models, are only those corresponding to the set of explanatory variables, which prove most significant and robust to specification. As mentioned, the effect of timing of liberalisation tend to be dominated by other variables for the depth if recession, where the impact of war and initial conditions (initial trade dependence on other command economies) is most critical.

However, as one would expect, initial conditions have smaller impact on the length of recessions, which is clearly dominated by stabilisation (equations (3) and (5)) and less clearly by liberalisation (equation (4)). Impact of initial conflicts (war) on the length 
of recession is highly insignificant (in contrast to its impact on the depth of recession) and the corresponding variable is not included in reported specifications.

One we combine both dimensions into one proxy of the cost of recessions, timing of both stabilisation and liberalisation seem to dominate the impact of initial conditions, with the negative impact of war remaining significant.

Generally, early stabilisation comes across as the significant predictor associated negatively with both the length and the depth of recession. We did additional checks, constructing a continuous variable representing exact timing of stabilisation and it worked equally well. Early liberalisation has also positive impact making recessions shorted, but does not come across as a significant predictor of the depth of recessions. In contrast, initial conditions count for the depth of recession, and far less for the length of recession. Specifically, the more open was a given economy to its Communist trade partners, the more serious was the effect of initial disruption in the trade patterns and contamination coming from neighbouring economies facing their own crises. This effect was particularly serious for smaller post-Soviet Union republics affected by initial slump in Russia, as demonstrated by Christoffersen and and Doyle (2000). Again, the effect of initial trade patterns on the depth of recession is robust and significant. Finally, the last dimension that emerges as very robust predictor of the depth of recession is the war indicator. It has also significant impact on the aggregate measure of the cost of recession.

Finally, in Table A.4, we present an alternative approach, where direct interdependence between the depth and length of recession is taken into account in a seemingly unrelated regression model. In this context, we return to the liberalisation indicator, which significance was slashed due to multicollinearity in the OLS regression models. The specification presented includes indicators of early stabilisation, early liberalisation and the war dummy. Here, early stabilisation seems to make the recession shorter by 2.4 years, and the effect is significant. It has no significant effect on the depth of recession. On the other hand, early liberalisation reduces the depth of the slump in output by $13 \%$ on average, but has no significant impact on the length of recession. And again, war leads to more serious slump, but its impact on the length of recession is highly insignificant (with wrong sign). 
To conclude. We know from the empirical literature on the GDP dynamics in transition economies that both liberalisation and some types of stabilisation programmes led to contemporaneous dip in output followed by strong recovery ( $\mathrm{J}$ curve effects). This is consistent with the results presented here. Economies which introduced effective stabilisation and liberalisation programmes early suffered less from the post-Communist recessions. However, the initial conditions were also important. More open, smaller economies suffered more, as they were more affected by the initial disruption in trade patters, after the Soviet block disintegrated. And finally, war is not good for growth. Czechs and Slovak who decided to separate without a single shot being fired, did much better than former republics of Yugoslavia (apart from Slovenia) and some of the former Soviet republics.

\section{Evaluation}

We intend to make a link between our results and the theoretical literature on recessions. Out focus will be on Blanchard-Kremer (1997). The first think however is to consider the empirical evidence provided by these authors.

Based on input-output tables for nine transition economies, they construct the index of complexity of production structures and find that it correlates with recession, controlling for an appropriate set of other variables. However, the problem with the estimations provided by Blanchard and Kremer (1997) is that we are unable to distinguish between the effects of full liberalisation and those of some partial reforms. In fact, their sample (Moldova, Macedonia, Kyrgyzstan, Georgia, Belarus, Azerbaijan, Armenia, Albania, Russia) relates to economies, which were not in the group of fast reformers at the time the data was collected.

Blanchard and Kremer (1997) notice the difference between the group of countries in the dataset used for econometric estimations and the Central European economies. They present additional OECD data showing that shortages of materials were no longer the major constraint for producers in Central Europe (Czech Republic, Hungary, Poland) in contrast to economies like Russia or Bulgaria, which still experienced serious problems. 
However, their provisional explanation is that the differences between the two groups of countries result from initial conditions, not from differences in economic policies and reforms. The two initial conditions they mention relate to the degree of centralisation in industrial structures and enterprises (and therefore more specialisation leading to negative impact of disorganisation) and to the distance to the main EU markets and volume of trade, which decease a possibility to alleviate the problems of specificity (Ibid., p.1122).

The first argument (centralisation) may be valid, the second (trade links) seems to be partly invalid, as demonstrated by the estimates reported earlier: more open economies suffered more not less from recessions - the negative effect of breaking the existing trade links was stronger than the positive effect of overcoming specificity.

More importantly however, the main contribution of our results may be to show that is not the difference in initial conditions, but in timing of the basic set of liberalisation measures and stabilisation that may be the key dimension explaining the postCommunist recessions. From the SUR regression reported earlier, we may see that early introduction of full liberalisation was linked to more shallow output slump (with the estimated difference being $13 \%$ of the 1989 GDP value).

All this does not invalidate the Blanchard and Kremer (1997) model, it may suggest however, the instead of being a general model of 'transitional recession' it may in fact be a more narrow model of disorganisation under partial liberalisation conditions. There are two possible lines of argument here.

Firstly, one may notice that liberalisation accompanied by the private sector growth has two dimensions. The first one is that the set of available transactions for existing suppliers expands, which may lead to a break down of existing production chains and decrease in the old sector output and recession, along the lines discussed above. The second effect however is the creation of new suppliers, which is likely to work the other way round: the increase in the number of suppliers is likely to decrease specificity and hold up problems, provide alternative opportunities for producers and thus increase output. In fact, Blanchard and Kremer (1997) notice a major important channel that may operate this way, that is, the availability of external options provided by foreign trade. However, the issue links more to liberalisation than initial conditions. While initial trade dependence had a negative effect (breaking down of 
old links), it is trade liberalisation and openness which led to new connections being established in place of old ones. More generally, to the extent that the entry of new suppliers takes time, the first (negative) dimension could still dominate early in transition; the second however, may prevail later on (provided there is sufficient freedom of entry). From this perspective, the recovery is brought not just by the efficient completion of the search and bargaining process aimed at the new equilibrium set of prices, but also, or even more importantly by entry of new suppliers.

A second argument, which would link the model to incomplete liberatisation is slightly different. Some prices along the production chain may be still controlled, while freedom of contract may be introduced early. That makes outside options more attractive, another words, a disrupting effect of partial liberalisation may be more serious than that of full liberalisation. For that reason, incomplete liberalisation may lead to the outcomes, where a combination of selective price controls and new outside options (including underground economy) lead to long lasting disruption. A good exemplification of that may be the situation which developed in the CIS area with underpriced energy coupled with inadequate control over sale decisions of enterprises, including illegal export (see Gros and Steinherr 2004). In general, it is likely that the disorganisation mechanism was one of the sources of 'transitional recessions', but had even more serious negative effects in case of partial liberalisations and incomplete transitions. To reiterate the empirical result: 'transitional recessions' caused by liberalisation were J-curve type phenomena. Slow liberalisations (i.e. partial liberalisations) and late stabilisations led to more prolonged and deeper slumps in output. 


\section{Appendix A. Data and Estimation results}

Table A.1 Timing of recession, liberalisation and stabilisation programmes

\begin{tabular}{|c|c|c|c|c|c|c|}
\hline Country & $\begin{array}{l}\text { Liberalisatio } \\
\mathrm{n} \\
\text { date }\end{array}$ & $\begin{array}{l}\text { Stabilisatio } \\
\mathrm{n} \\
\text { programme } \\
\text { date }\end{array}$ & $\begin{array}{l}\text { Beginning } \\
\text { of } \\
\text { recession }\end{array}$ & $\begin{array}{l}\text { Last year } \\
\text { of } \\
\text { recession }\end{array}$ & $\begin{array}{l}\text { Length } \\
\text { of } \\
\text { recession }\end{array}$ & $\begin{array}{l}\text { Lowest } \\
\text { output / } \\
1989 \text { value }\end{array}$ \\
\hline \multicolumn{7}{|c|}{ Central Europe and South Eastern Europe } \\
\hline Albania & 1993 & 1992 & 1990 & 1992 & 3 & 0.604 \\
\hline Bosnia & 1998 & 1997 & 1989 & 1994 & 6 & 0.120 \\
\hline Bulgaria & 1994 & 1997 & 1990 & 1997 & 8 & 0.632 \\
\hline Croatia & 1991 & 1993 & 1989 & 1993 & 5 & 0.595 \\
\hline Czech Republic & 1991 & 1991 & 1990 & 1992 & 3 & 0.846 \\
\hline Estonia & 1993 & 1992 & 1989 & 1994 & 6 & 0.608 \\
\hline FYR Macedonia & 1991 & 1994 & 1989 & 1995 & 7 & 0.551 \\
\hline Hungary & 1992 & 1990 & 1990 & 1993 & 4 & 0.819 \\
\hline Latvia & 1993 & 1992 & 1991 & 1995 & 5 & 0.510 \\
\hline Lithuania & 1993 & 1992 & 1990 & 1994 & 5 & 0.533 \\
\hline Poland & 1990 & 1990 & 1990 & 1991 & 2 & 0.822 \\
\hline Romania & 1994 & 1993 & 1989 & 1992 & 4 & 0.750 \\
\hline Serbia & 2001 & 1993 & 1989 & 1993 & 5 & 0.400 \\
\hline Slovakia & 1991 & 1991 & 1990 & 1993 & 4 & 0.750 \\
\hline Slovenia & 1991 & 1992 & 1989 & 1992 & 4 & 0.820 \\
\hline \multicolumn{7}{|c|}{ Commonwealth of Independent States } \\
\hline Armenia & 1996 & 1994 & 1990 & 1993 & 4 & 0.310 \\
\hline Azerbaijan & 1998 & 1995 & 1989 & 1995 & 7 & 0.370 \\
\hline Belarus & not yet & 1994 & 1990 & 1995 & 6 & 0.627 \\
\hline Georgia & 1996 & 1994 & 1989 & 1994 & 6 & 0.254 \\
\hline Kazakhstan & 1995 & 1994 & 1989 & 1995 & 7 & 0.612 \\
\hline Kyrgyzstan & 1994 & 1993 & 1991 & 1995 & 5 & 0.504 \\
\hline Moldova & 1995 & 1993 & 1990 & 1999 & 10 & 0.317 \\
\hline Russia & 1993 & 1995 & 1990 & 1998 & 9 & 0.553 \\
\hline Tajikistan & 2000 & 1995 & 1989 & 1996 & 8 & 0.392 \\
\hline Turkmenistan & not yet & 1997 & 1989 & 1997 & 9 & 0.420 \\
\hline Ukraine & 1996 & 1994 & 1990 & 1999 & 10 & 0.365 \\
\hline Uzbekistan & not yet & 1994 & 1991 & 1995 & 5 & 0.834 \\
\hline
\end{tabular}

Notes:

(i) Liberalisation: year when the average of the three EBRD liberalisation indicators (price liberalisation, external liberalisation and small privatisation) takes value of 3 or higher (with price liberalisation indicator based on pre-2003 EBRD definition, adjusted where necessary to preserve compatibility). Source: EBRD (1995-2004) and Falcetti et al. (2002).

(ii) Stabilisation: year when successful stabilisation programme was introduced (i.e. for countries with recurring high inflation episodes, the second date is reported; example: Bulgaria). Source EBRD (1999-2004).

(iii) Timing of recession: based on EBRD (1995-2004) and World Bank, World Development Indicators (2001 dataset).

(iv) Lowest value of output (depth of recession): based on EBRD (1995-2004). 
Table A.2 More explanatory variables

\begin{tabular}{|c|c|c|c|c|c|c|c|}
\hline Country & $\begin{array}{l}\text { Wa } \\
\mathrm{r}\end{array}$ & $\begin{array}{l}\text { Years } \\
\text { under } \\
\text { communism }\end{array}$ & $\begin{array}{l}\text { Rich } \\
\text { resourc } \\
\text { e } \\
\text { base }\end{array}$ & $\begin{array}{l}\text { Represse } \\
\text { d } \\
\text { Inflation } \\
1987- \\
1989\end{array}$ & $\begin{array}{l}\text { Black } \\
\text { market } \\
\text { exchange } \\
\text { rate } \\
\text { premium } \\
1990(\%)\end{array}$ & $\begin{array}{l}\text { Trade } \\
\text { Dependenc } \\
\text { e } \\
1990(\%)\end{array}$ & $\begin{array}{l}\text { Formerly } \\
\text { part of } \\
\text { federation } \\
\text { (USSR, } \\
\text { Yugoslavia } \\
\text { CSSR) }\end{array}$ \\
\hline \multicolumn{8}{|c|}{ Central Europe and South Eastern Europe } \\
\hline Albania & 0 & 45 & 0 & 4.3 & 434 & 6.6 & 0 \\
\hline Bosnia & 1 & 44 & 0 & 12 & 27 & 6 & 0 \\
\hline Bulgaria & 0 & 43 & 0 & 18 & 981 & 16.1 & 0 \\
\hline Croatia & 1 & 44 & 0 & 12 & 27 & 6 & 1 \\
\hline Czech Republic & 0 & 43 & 0 & -7.1 & 185 & 6 & 1 \\
\hline Estonia & 0 & 51 & 0 & 25.7 & 1828 & 30.2 & 1 \\
\hline FYR Macedonia & 0 & 44 & 0 & 12 & 27 & 6 & 1 \\
\hline Hungary & 0 & 41 & 0 & -7.7 & 46.7 & 13.7 & 0 \\
\hline Latvia & 0 & 51 & 0 & 25.7 & 1828 & 36.7 & 1 \\
\hline Lithuania & 0 & 51 & 0 & 25.7 & 1828 & 40.9 & 1 \\
\hline Poland & 0 & 42 & 1 & 13.6 & 277 & 8.4 & 0 \\
\hline Romania & 0 & 43 & 1 & 16.8 & 728 & 3.7 & 0 \\
\hline Serbia & 1 & 44 & 0 & 12 & 27 & 6 & 1 \\
\hline Slovakia & 0 & 43 & 0 & -7.1 & 185 & 6 & 1 \\
\hline Slovenia & 0 & 44 & 0 & 12 & 27 & 4 & 1 \\
\hline \multicolumn{8}{|c|}{ Commonwealth of Independent States } \\
\hline Armenia & 1 & 74 & 0 & 25.7 & 1828 & 25.6 & 1 \\
\hline Azerbaijan & 1 & 75 & 2 & 25.7 & 1828 & 29.8 & 1 \\
\hline Belarus & 0 & 75 & 0 & 25.7 & 1828 & 41 & 1 \\
\hline Georgia & 1 & 70 & 0 & 25.7 & 1828 & 24.8 & 1 \\
\hline Kazakhstan & 0 & 75 & 2 & 25.7 & 1828 & 20.8 & 1 \\
\hline Kyrgyzstan & 0 & 75 & 0 & 25.7 & 1828 & 27.7 & 1 \\
\hline Moldova & 1 & 52 & 0 & 25.7 & 1828 & 28.9 & 1 \\
\hline Russia & 1 & 74 & 2 & 25.7 & 1828 & 11.1 & 1 \\
\hline Tajikistan & 1 & 75 & 0 & 25.7 & 1828 & 31 & 1 \\
\hline Turkmenistan & 0 & 75 & 2 & 25.7 & 1828 & 33 & 1 \\
\hline Ukraine & 0 & 75 & 1 & 25.7 & 1828 & 23.8 & 1 \\
\hline Uzbekistan & 0 & 75 & 1 & 25.7 & 1828 & 25.5 & 1 \\
\hline
\end{tabular}

\section{Notes:}

(i)

(ii)
War: a military conflict, either internal or with neighbouring countries (based on author's assessment) Number of years a country spent under communism and indicator of rich resource base: both based on Fisher and Sahay (2000).

Black market exchange rate premium and trade dependence, both based on De Melo et al. (1997).

Trade dependence defined as average of exports and imports divided by GDP. 
Table A.3 Determinants of Post-Communist Recessions

\begin{tabular}{|c|c|c|c|c|c|c|c|c|}
\hline \multirow{2}{*}{$\begin{array}{l}\text { Dependent } \\
\qquad \text { Variable } \\
\text { Explanatory } \\
\text { Variables } \\
\end{array}$} & \multicolumn{2}{|c|}{$\begin{array}{l}\text { Depth of recession: } \\
\text { Lowest value of output / } \\
1989 \text { value of output }\end{array}$} & \multicolumn{2}{|c|}{$\begin{array}{l}\text { Length of recession } \\
\text { in years }\end{array}$} & \multicolumn{2}{|c|}{$\begin{array}{l}\text { Time recession ended relative to } \\
1989 \\
\text { (year of lowest } \\
\text { output }+1-1989 \text { ) }\end{array}$} & \multicolumn{2}{|c|}{$\begin{array}{l}\text { Cost of recession; } \\
\text { a proxy calculated as: } \\
{[1-(\text { lowest output / } 1989 \text { output })]^{*}} \\
\text { (length of recession) }\end{array}$} \\
\hline & $(1)$ & (2) & (3) & (4) & $(5)$ & (6) & (7) & (8) \\
\hline $\begin{array}{l}\text { Stabilisation before 199 } \\
\text { (dummy variable) }\end{array}$ & $.088(.063)$ & & $-2.536 * * *(.673)$ & & $-2.143 * *(.674)$ & & $-1.456^{*}(.623)$ & \\
\hline $\begin{array}{l}\text { Liberalisation before } 1 \\
\text { (dummy variable) }\end{array}$ & & $.100(.065)$ & & $-1.576 \dagger(.809)$ & & $-1.039(.797)$ & & $-1.265 \dagger(.672)$ \\
\hline $\begin{array}{l}\text { Initial trade dependenc } \\
\text { (def. as in Table A.2) }\end{array}$ & $-.005^{*}(.002)$ & $-.004(.002)$ & $.054 *(.026)$ & $.042(.033)$ & $.072 *(.026)$ & $.066 \dagger(.032)$ & $.049 *(.021)$ & $.036(.024)$ \\
\hline $\begin{array}{l}\text { War dummy } \\
\text { (def. as in Table A.2) }\end{array}$ & $-.236 * * *(.062)$ & $-.229 * *(.062)$ & & & & & $1.350 *(.618)$ & $1.437 *(.649)$ \\
\hline Constant & $.699 * * *(.063)$ & $.648 * * *(.084)$ & $5.618 * * *(.655)$ & $5.891 * * *(.98)$ & $5.819 * * *(.656)$ & $5.796 * * *(.97)$ & $1.907 * *(.632)$ & $2.346 *(.877)$ \\
\hline Number of observation & 27 & 27 & 27 & 27 & 27 & 27 & 27 & 27 \\
\hline F statistics & $12.02 * * *$ & $12.37 * * *$ & $10.51 * * *$ & $4.37 *$ & $10.16^{* * *}$ & $4.70 *$ & $9.35 * * *$ & $8.21 * * *$ \\
\hline R-squared & .611 & .617 & .467 & .267 & .459 & .282 & .550 & .517 \\
\hline Adjusted R-squared & .560 & .567 & .422 & .206 & .414 & .222 & .491 & .454 \\
\hline
\end{tabular}

Notes:

(i) estimator: ordinary least squares

(ii) standard errors in parentheses

(iii) significance levels: $* * * .001 ; * * .01 ; * .05 ; \dagger 0.1$. 
Table A.4 Determinants of Post-Communist Recessions: seemingly unrelated regression model

\begin{tabular}{|c|c|c|c|}
\hline $\begin{array}{l}\text { Explanatory } \\
\text { Variables } \\
\end{array}$ & $\begin{array}{l}\text { Dependent } \\
\text { Variables }\end{array}$ & $\begin{array}{l}\text { Depth of recession: } \\
\text { Lowest value of output / } \\
1989 \text { value of output }\end{array}$ & $\begin{array}{l}\text { Length of recession } \\
\text { in years }\end{array}$ \\
\hline $\begin{array}{l}\text { Stabilisation before } 1993 \\
\text { (dummy variable) }\end{array}$ & & $.040(.075)$ & $-2.418 *(.989)$ \\
\hline $\begin{array}{l}\text { Liberalisation before } 1995 \\
\text { (dummy variable) }\end{array}$ & & $.131 \dagger(.070)$ & $-.647(.923)$ \\
\hline $\begin{array}{l}\text { War dummy } \\
\text { (def. as in Table A.2) }\end{array}$ & & $-.191 * *(.066)$ & $-.255(.870)$ \\
\hline Constant & & $.530 * * *(.055)$ & $7.065 * * *(.725)$ \\
\hline Number of observations & & 27 & 27 \\
\hline F statistics & & $10.42 * * *$ & $4.78 * *$ \\
\hline R-squared & & .576 & .384 \\
\hline
\end{tabular}

Notes:

(i) estimator: Zellner's seemingly unrelated regression model

(ii) covariance matrix for the residuals computed with a small sample adjustment

(iii) standard errors in parentheses

(iv) significance levels (for coefficients, based on $t$-statistics): ***.001;**.01;*.05; $\uparrow 0.1$

(v) Correlation of residuals from the two equations: $-.367 ; \chi^{2}(1)=3.629 \dagger$. 


\section{Bibliography}

Aslund, A. (2001) 'The Myth of Output Collapse after Communism', Carnegie Endowment for International Peace Working Paper, 18.

Blanchard, O. (1997) The Economics of Post-Communist Transition (Oxford: Clarendon Press).

Blanchard, O. and M. Kremer (1997), 'Disorganisation', Quarterly Journal of Economics, 112, 1091-1126.

Calvo, G. and F. Coricelli (1992), 'Stagflationary Effects of Stabilisation Programmes in Reforming Socialist Countries: Enterprise-Side and Household-Side Factors', The World Bank Economic Review, 6, 71-90.

Calvo, G. and F. Coricelli (1993) 'Output Collapse in Eastern Europe: The Role of Credit', IMF Staff Papers, 40, 1, 32-52.

Campos, N. and F. Coricelli (2002), 'Growth in Transition; What We Know, What We Don't and What We Should', Journal of Economic Literature, 60, 793836.

Christoffersen, P. and P. Doyle (2000), 'From Inflation to Growth. Eight Years of Transition', Economics of Transition, 8, 421-451.

De Melo, M., C. Denizer, A. Gelb and S. Tenev (1997), 'Circumstance and Choice. The Role of Initial Conditions and Policies in Transition Economies', World Bank Policy Research Working Paper, 1866.

Desai, P. and T. Idson (2000) Work Without Wages. Russia's Nonpayment Crisis (Cambridge, MA: The MIT Press).

EBRD (1994-2004) Transition Reports (London: European Bank for Reconstruction and Development)

Earle, J. and Estrin, S. (1996) 'Employee Ownership in Transition', in R. Frydman, C. Gray, A. Rapaczynski (eds.), Corporate Governance in Central Europe and Russia (Budapest: CEU Press), 2, 1-61.

Falcetti, E., M. Raiser and P. Sanfey (2002) 'Defying the Odds: Initial Conditions, Reforms, and Growth in the First Decade of Transition', Journal of Comparative Economics, 30, 229-250.

Fisher, S. and R. Sahay (2000), 'The Transition Economies after Ten Years', IMF Working Paper, WP/00/30.

Gros, A. and D. Steinherr (2004) Economic Transition in Central and Eastern Europe (Cambridge: Cambridge University Press).

Gros, A. and M. Suhrcke (2000) 'Ten Years After: What is Special about Transition Economies', EBRD Working Paper, 56.

Havrylyshyn, O. and R. van Rooden (2003), Comparative Economic Studies, 45, 224.

Kornai, J. (1995) "Transformational Recession: The Example of Hungary", in: C. Sanders (ed.), Eastern Europe in Crisis and the Way Out (Houndmills: Macmillan), 29-77.

McKinnon, R. (1993), The Order of Economic Liberalisation (Baltimore: Johns Hopkins University Press).

Portes, R. (ed.) (1993), Economic Transformation in Central Europe (London: CEPR). 